\title{
Guest Editors' Introduction II: Reflections on Scholarship and Activism in Canada and Ireland
}

SANDRA SMELTZER

The University of Western Ontario, Canada

SARA CANTILLON

Glasgow Caledonian University, Ireland

This second of two back-to-back special issues for Studies in Social Justice (SSJ) features articles that offer a spectrum of case studies addressing the relationship between scholarship and activism in Canada and Ireland. As the guest editors of these two issues, we requested that the authors, who represent a range of disciplines and positions in their respective institutions of higher education, employ a critical and self-reflexive lens to examine the challenges and rewards associated with negotiating their roles as scholars and activists.

In collaboration with myriad organizations and networks, these authors strive for greater social justice within their local communities. Their efforts are, however, hampered by the unrelenting encroachment of neoliberalism within and beyond the 'ivory tower.' Consequently, many focus their discussion on the rising levels of managerialism and corporatization within higher education, highlighting the metrics-oriented response to austerity measures that forefronts monetizable 'deliverables' and, in the process, negatively impacts the ability of academics to engage in activist endeavours (see in this issue Brulé; Giroux, Karmis \& Rouillard; Hawthorne-Steele, Moreland \& Rooney; Luka, Harvey, Hogan, Shepherd \& Zeffiro; Murphy; and Visser; see also, e.g., Mercille \& Murphy, 2015; Walsh \& Loxley, 2014; Washburn, 2005).

The shift toward greater neoliberalism - both within higher education and society writ large - has also led to a growing contingency of precarious academic labour, a prominent theme in contemporary scholarship that has animated both special issues. In this collection, Giroux, Karmis \& Rouillard; Luka, Harvey, Hogan, Shepherd \& Zeffiro; and Murphy all note in their 
concluding remarks that being in a tenured, or at least a tenure-track, position provides the job security and the work flexibility necessary to pursue activism, as well as (for many) the confidence to articulate potentially controversial opinions without fear of reprisal. These capacities are, however, under threat at all levels of the scholarly hierarchical system by the internal and external pressures that are placed on academics to align their teaching and research with market principles, and to remain politically benign in both their professional and private lives. As Giroux, Karmis, and Rouillard argue quite emphatically in their article, all academics must have the freedom to express themselves and to speak openly without interference or sanction (see also, e.g., CAUT, 2011; Hanke \& Hearn, 2012; Turk, 2014; Woodhouse, 2009).

Collectively, then, the most prominent theme underpinning the articles in this issue is the ramifications of neoliberal policies and practices on precarious labour, institutional governance, academic freedom, and research 'outputs' or 'deliverables.' Notwithstanding these very legitimate concerns, many of the authors also conveyed optimism - albeit with some caveats that scholars can indeed make a positive difference through advancing social justice.

For most of the contributors, though, this is their first foray into writing for a peer-reviewed publication about their lived experience negotiating the terrain of scholarship and activism. These authors conveyed to us that the process of writing and editing their manuscript provided greater insight into their own practices and perspectives. As a result, the experience was quite (if unexpectedly) personal, which is reflected in the more intimate tone of their pieces. Other authors struggled with our request for self-reflexivity. Their reluctance could, in part, be attributed to concerns about the potentially lessthan-perfect outcomes of a specific experience, feeling that personal reflections of this nature do not belong in an academic venue, or that they risk jeopardizing scholarly or activist relationships if they are too honest about the challenges of their work (e.g., Ellis \& Bochner, 2000).

Lastly, in comparison to the first special issue, there are fewer tensions between the authors' opinions regarding what constitutes legitimate or strategic methods of furthering social justice. Most lean toward a reformist approach or hover somewhere in the middle of the reformist versus revolutionary/radical spectrum, as their primary objective is not to abolish dominant political and economic frameworks. The articles written by Brulé, and by Giroux, Karmis, and Rouillard, both of which challenge institutional governance on campus, are notable exceptions (for context, see Croteau, 2005; James \& Gordon, 2008; Young \& Schwartz, 2012).

We now turn our attention to an overview of each of the articles, starting with on campus forms of activism and working our way outward to activism undertaken by authors within their respective off campus communities. These synopses illuminate the similarities that exist between the experiences of 
Canadian and Irish scholar-activists with respect to promoting and supporting social justice.

\section{Overview of Articles}

In the opening article, Dalie Giroux, Dimitrios Karmis, and Christian Rouillard focus their discussion on governance at the University of Ottawa. Through a close reading of their home institution's administration-heavy and market-oriented governance structure, the authors illustrate how the university's core mission of contributing to democratic life is being eroded by the rise of managerialism. In particular, this assault on the democratic university and its collegial governance has negatively impacted scholars' academic freedom. In the second half of their article, Giroux, Karmis, and Rouillard broaden the scope of their analysis to compare how academic freedom is framed by the Canadian Association of University Teachers versus the more narrowly focused version advanced by Universities Canada (formerly the Association of Universities and Colleges of Canada). The authors conclude by calling on "unions, associations, departments, and individuals" to stymie the shift toward the latter's managerial version of a university, starting with demanding change in governance structures to more appropriately reflect the university community (i.e., faculty, students, and staff) rather than business interests.

In a similar vein, Elizabeth Brulés article offers an in-depth look into the governance structure of another Canadian institution - York University in Toronto. Drawing on an institutional ethnography framework, Brulé examines how her administration's discourse on rights and responsibilities has been concretized into policy documents aimed at minimizing political conflict on campus, especially among the student population. Problematically, these text-based forms of regulation have served to limit all forms of student advocacy and activism and, in the process, have often violated rights that should be protected under the Canadian Charter of Rights and Freedoms. Brulé also describes the range of complementary coercive mechanisms and risk management techniques used by the administration to control physical and discursive spaces on campus to ensure that both align with corporate values. She concludes the article with recent examples that demonstrate, again in like manner to Giroux, Karmis, and Rouillard, that this trend can be reversed if we collectively work together to support and protect academic freedom, the rights of students, and the democratic role of the university.

The issue of precarious academic labour is a key theme in the article by Luka, Harvey, Hogan, Shepherd, and Zeffiro, which examines the idea of scholarly work as cultural production. On the one hand, the concept of scholarship as cultural production within the corporatized university is articulated through economically productive deliverables, including a 
narrowly defined set of public engagement and outreach activities, such as public talks and media appearances designed primarily to promote university products and personalities to the general public and to funders who seek 'impact.' On the other hand, the authors contend that scholarship as cultural production should include participation in work, research, and creative endeavours both inside and outside the academic sphere, including the roles played by public intellectuals and community activists. The article draws on a sampling of online discussions, combined with concerns raised at two academic conference roundtables (in 2013 and 2014), about how the neoliberal environment produces academic precarity. Their findings suggest that by engaging in a sustained interrogation of the conditions under which academic labour is performed, critical knowledge is produced that needs to be transmitted to university administrators, as well as through public dialogue. The authors conclude by stressing the importance of job security to such freedom of expression.

Isobel Hawthorne-Steele, Rosemary Moreland, and Eilish Rooney also straddle the line between on and off campus activism. The authors describe and examine the pedagogical practices they undertake to help ameliorate educational disadvantage in areas affected by conflict in Northern Ireland. They focus their discussion specifically on Ulster University's Community Development Program, which they developed to provide individuals from disadvantaged communities with an opportunity to participate in higher education. Drawing on Paulo Freire's pedagogy of hope, this learner-led program strives to critically marry theory and praxis, to incorporate critical reflection, and to foment conscientization among students who live and work in their respective communities. Hawthorne-Steele, Moreland, and Rooney also acknowledge some of the challenges associated with this type of pedagogical activism, especially in a politically charged environment in which students may hold deeply ingrained, polarized positions or may avoid the demanding process of self-reflection.

Mary Murphy's article offers readers insight into the professional and personal difficulties she faces in trying to balance her position as a tenured faculty member with her long-standing involvement in Ireland's civil society. Describing herself as a 'pracademic,' Murphy has consciously chosen to take more of a reformist approach to her activism with various government entities and social justice-oriented organizations, while also negotiating a neoliberal system of higher education that tries to stifle socio-political activism. She addresses the challenges associated with having her efforts dismissed as being "biased" by voices in both spheres, and the risk that her work will be co-opted by special interests (especially by state actors). Similar to other authors in this issue, Murphy concludes her article by emphasizing the importance of job security for scholar-activists, especially given the strains of also fulfilling familial commitments, and makes the case that critical scholarship does indeed play a central role in fostering the collective solidarities necessary to foment social change. 
As a counterpart to Murphy's discussion, Anna Visser's article explores the relationship between scholar-activists and civil society activists in Ireland, focusing on what each group can learn from the other regarding the advantages and drawbacks of receiving state funding. Drawing on her own extensive background working in Ireland's civil society, Visser outlines the obstacles domestic organizations face if they choose to accept state funding. While she appreciates the serious concerns expressed in some quarters regarding the negative ramifications of accepting such financial support, she maintains its importance for buttressing the democratic role civil society organizations play in the country, and contends that most of these organizations are in fact aware of their precarious position and thus capable of the self-reflexivity necessary to manage potential risks. Under the rubric of austerity, activists based in the academy face similar challenges, which should, Visser argues, lead to greater cooperation with civil society activists in order to productively utilize government funding.

In the concluding article for this issue, author Sarah Wiebe provides an interesting case study that takes place entirely off campus. Wiebe examines her experience collaborating on the production of the film Indian Givers, which tells the story of Indigenous youth growing up in a polluted environment in Southwestern Ontario. The film's primary objectives are to raise awareness about the socio-political issues affecting these youth, to promote social change in the local community, and to challenge Western models of knowledge. Informed by intersectionality theory, Wiebe explores the benefits of co-creating this visual medium, as well as some of the key challenges of such community engaged scholarship within a colonial context. Drawing on Chantal Mouffe's theory of agonism, she underscores the importance of respecting differences in knowledge, perspectives, and expertise, which eschew hierarchical relationships, especially between the 'researcher' and the 'researched.'

Finally, as the guest co-editors, we want to thank David Butz for the generous amount of time and energy he has dedicated to bringing this second issue to fruition. He has, once again, gone above and beyond in his capacity as Editor-in-Chief of Studies in Social Justice.

\section{References}

CAUT (Canadian Association of University Teachers). (2011). CAUT policy statements: Academic freedom. Retrieved from www.caut.ca/about-us/caut-policy/lists/caut-policystatements/policy-statement-on-academic-freedom

Croteau, D. (2005). Which side are you on? The tension between movement scholarship and activism. In D. Croteau, W. Hoynes \& C. Ryan (Eds.), Rhyming hope and history: Activists, academics, and social movement scholarship (pp. 20-40). Minneapolis: University of Minnesota Press.

Ellis, C.S., \& Bochner, A. (2000). Autoethnography, personal narrative, reflexivity: Researcher as dubject. In N. Denzin \& Y. Lincoln (Eds.), The handbook of qualitative research $\left(2^{\text {nd }}\right.$ ed.) (pp. 733-768). Thousand Oaks, California: Sage. 
Hanke, B., \& Hearn, A. (2012). Introduction: Out of the ruins, the university to come. Topia: Canadian Journal of Cultural Studies, 28, 11-20.

James, J., \& Gordon, E.T. (2008). Activist scholars or radical subjects? In C.R. Hale (Ed.), Engaging contradictions: Theory, politics, and methods of activist scholarship (pp. 367373). Berkeley: University of California Press.

Mercille, J., \& Murphy, E. (2015). The neoliberalization of Irish higher education under austerity. Critical Sociology (DOI: 10.1177/0896920515607074). Retrieved from http://crs.sagepub.com/content/early/2015/10/07/0896920515607074.full.pdf

Turk, J.L. (Ed.). (2014). Academic freedom in conflict: The struggle over free speech rights in the University. Toronto: James Lorimer \& Company.

Walsh, J., \& Loxley, A. (2014). The Hunt Report and higher education policy in the Republic of Ireland: 'An international solution to an Irish problem?' Studies in Higher Education, 40(6), 1128-1146.

Washburn, J. (2005). University, Inc.: The corporate corruption of American higher education. New York: Basic Books.

Woodhouse, H. (2009). Selling out: Academic freedom and the corporate market. Montreal \& Kingston: McGill-Queen's University Press.

Young, K., \& Schwartz, M. (2012). Can prefigurative politics prevail? The implications for movement strategy in John Holloway's Crack Capitalism. Journal of Classical Sociology, $12(2), 220-239$ 